九州大学学術情報リポジトリ

Kyushu University Institutional Repository

\title{
Supplementary Effect of Hydrogen Peroxide as a Pre-disinfectant for Sterilizing Rhizome Bud Explants of Zantedeschia aethiopica L. with Chlorine Dioxide
}

Chen, Li-Ru

Laboratory of Horticultural Science, Department of Bioresource Science, Faculty of Agriculture, Kyushu University | Department of Horticulture and Biotechnology, Chinese Culture University

Hsiung, Tung-Chuan

Laboratory of Horticultural Science, Department of Bioresource Science, Faculty of Agriculture, Kyushu University | Department of Horticulture and Biotechnology, Chinese Culture University

Lin, Kuan-Hung

Laboratory of Horticultural Science, Department of Bioresource Science, Faculty of Agriculture, Kyushu University | Department of Horticulture and Biotechnology, Chinese Culture University

Huang, Tzu-Bin

Laboratory of Horticultural Science, Department of Bioresource Science, Faculty of Agriculture, Kyushu University | Department of Horticulture and Biotechnology, Chinese Culture University

他

https://doi.org/10.5109/1799306

出版情報 : 九州大学大学院農学研究院紀要. 62 (1), pp. 81-86, 2017-02-24. Faculty of Agriculture， Kyushu University

バージョン :

権利関係 : 


\title{
Supplementary Effect of Hydrogen Peroxide as a Pre-disinfectant for Sterilizing Rhizome Bud Explants of Zantedeschia aethiopica L. with Chlorine Dioxide
}

\author{
Li-Ru CHEN ${ }^{1}$, Tung-Chuan HSIUNG ${ }^{1 *}$, Kuan-Hung LIN $^{1}$, Tzu-Bin HUANG ${ }^{1}$, \\ Meng-Yuan HUANG ${ }^{1}$ and Akira WAKANA
}

\author{
Laboratory of Horticultural Science, Department of Bioresource Science, Faculty of Agriculture, \\ Kyushu University, Fukuoka, 812-8581, Japan \\ (Received October 28, 2016 and accepted November 4, 2016)
}

\begin{abstract}
Zantedeschia spp. (calla lily) are ornamental tuberous/rhizomatous plants of economic importance worldwide. In vitro micropropagation techniques have been widely used to mass-produce virus-free calla lilies. However, effective removal of contaminants is a major problem for the in vitro establishment of the calla lily propagation. In this study, we applied hydrogen peroxide $\left(\mathrm{H}_{2} \mathrm{O}_{2}\right)$ as a pre-disinfectant for sterilizing rhizome bud explants of $Z$. aethiopica followed by sterilization with sodium hypochlorite ( $\mathrm{NaOCl}$ ) or chlorine dioxide $\left(\mathrm{ClO}_{2}\right)$ to eliminate in vitro contamination. Results showed that application of $5 \%(\mathrm{w} / \mathrm{v}) \mathrm{H}_{2} \mathrm{O}_{2}$ for 5 minutes followed by $1 \%$ (w/v) $\mathrm{NaOCl}$ or $60 \sim 180 \mathrm{mg} \cdot \mathrm{L}^{-1} \mathrm{ClO}_{2}$ for 15 minutes significantly reduced the contamination rate to $<38 \%$ while maintaining the vigor of explant tissues. Surviving explants sterilized with $\mathrm{H}_{2} \mathrm{O}_{2}$ followed by $\mathrm{ClO}_{2}$ exhibited a higher rate (>75\%) of those showing shoot development than those sterilized with $\mathrm{NaOCl}$ (54\%). The two-step sterilization method with $\mathrm{H}_{2} \mathrm{O}_{2}$ and $\mathrm{ClO}_{2}$ synergistically optimized the disinfection efficiency and explants viability.
\end{abstract}

Key words: calla lily, in vitro contamination, pre-sterilization, shoot tip, viability

\section{INTRODUCTION}

An optimal sterilization method for eliminating contamination from explants and for maintaining their viability is an important initial step in establishing in vitro cultures. Hypochlorites are the most commonly used disinfectants for sterilizing explants, generally in the forms of inorganic sodium hypochlorite $(\mathrm{NaOCl})$, calcium hypochlorite, or mercuric chloride (Chen et al., 2002; Maina et al., 2010; Mihaljević et al., 2013). Nevertheless, hypochlorites are less efficient against dormant endospores and biofilm bacteria (Rutala and Weber, 1997; Gagnon et al., 2005), and only undissociated hypochlorites at neutral $\mathrm{pH}$ can penetrate across microbial plasma membranes, resulting in metabolic maladjustment, phospholipid destruction, and the formation of toxic chloramines (Fukuzaki, 2006).

Zantedeschia spp. (calla lilies), the Araceae family, are perennial bulbous plants native to southern Africa and are highly valued as cut flowers and ornamental potted plants worldwide (Ghimire et al., 2012). More than 90\% of Z. aethiopica in Taiwan is cultivated in Zhuzihu, Yang Ming Shan National Park. Calla lily festival was held annually during the blossom period of March to May with the meaning of art, culture and natural ecology, which promote the development of rural agritourism. Rhizomes and tubers have been widely utilized as explants for in vitro mass propagation of healthy and virus-free calla lilies (Kritzinger et al., 1998; Chang et al., 2003; Ebrahim, 2004). However, effective elimina-

\footnotetext{
1 Department of Horticulture and Biotechnology, Chinese Culture University, Taipei 11114, Taiwan

* Corresponding author (E-mail: clr2@faculty.pccu.edu.tw)
}

tion of contaminants from soil-grown materials is more difficult than from non-soil-grown organs. Z. aethiopica is commonly cultivated in marshy areas, and the elimination of contaminants from rhizome bud explants is a puzzling challenge with in vitro culture. Kritzinger et al. (1998) reported that incubation of sterilized rhizome bud explants in antibiotics for a long period of 5 days subsequent to pretreatment with fungicides and sterilization with $2 \%(\mathrm{w} / \mathrm{v}) \mathrm{NaOCl}$ decreased in vitro contamination rate from $90 \%$ to $10 \%$. Other methods with $4 \%$ $\mathrm{NaOCl}$ for 5 minutes (Ebrahim, 2004) or pretreatment with fungicides followed by $3 \% \mathrm{NaOCl}$ for 10 minutes (Chang et al., 2003) were frequently applied for the micropropagation of $Z$. aethiopica; however, the in vitro contamination and survival rates were not mentioned. Nevertheless, a high concentration of hypochlorite or long exposure to fungicides or antibiotics may cause phytotoxicity and the emergence of antibiotic-resistant bacterial strains (Mngómba et al., 2012).

Consequently, alternative disinfectants have been widely developed for improving the efficacy and safety of sterilization, such as hydrogen peroxide $\left(\mathrm{H}_{2} \mathrm{O}_{2}\right)$ and liquid chloride dioxide $\left(\mathrm{ClO}_{2}\right)$, disinfectants with antibacterial, fungicidal, endosporicidal, and virucidal activities (Srebernich, 2007; Linley et al., 2012). $\mathrm{H}_{2} \mathrm{O}_{2}$ is a neutral and small-sized molecule that can rapidly penetrate membranes of microorganisms to trigger the production of free hydroxyl radicals and oxidation of DNA, proteins, and membrane lipids without generating toxic by-products (Linley et al., 2012). $\mathrm{ClO}_{2}$ is a size-selective biocide specific to micron-sized organisms with minimal risk of developing resistant bacteria, that can rapidly penetrate biofilms in the molecular form and kill microbes living within the biofilm (Gagnon et al., 2005; Herczegh et 
al., 2013; Noszticzius et al., 2013). In addition, $\mathrm{ClO}_{2}$ can also detoxify excess reactive oxygen species (ROS) and induce antioxidant defense systems to prevent membrane damage from free radicals (Chomkitichai et al., 2014). For plant disease control, $\mathrm{ClO}_{2}$ exhibits inhibitory effects against phytopathogens, which cause black scurf sclerotia of potato, bacterial wilt of water convolvulus, and bacterial soft rot of calla lily (Errampalli et al., 2006; Yoa et al., 2010).

With advantages of high disinfection efficiency and low phytotoxicity, $\mathrm{H}_{2} \mathrm{O}_{2}$ and $\mathrm{ClO}_{2}$ were used to substitute for autoclaving to sterilize culture medium of Lilium longiflorum (Curvetto et al., 2006) and gerbera (Cardoso and da Silva, 2012), respectively. Furthermore, $\mathrm{H}_{2} \mathrm{O}_{2}$ and $\mathrm{ClO}_{2}$ are also used to sterilize explants of cauliflower, yacon, and pomegranate (Bhawana et al., 2015; Duan et al., 2016). In this study, we evaluated the supplementary effects of $\mathrm{H}_{2} \mathrm{O}_{2}$ as a pre-disinfectant followed by $\mathrm{NaOCl}$ and the synergistic effects of $\mathrm{H}_{2} \mathrm{O}_{2}$ and $\mathrm{ClO}_{2}$ on rhizome bud explants of $Z$. aethiopica to decrease in vitro contamination and maintain the shoot development. The hypothesis was that $\mathrm{H}_{2} \mathrm{O}_{2}$ could work synergistically with $\mathrm{NaOCl}$ or $\mathrm{ClO}_{2}$ to optimize the disinfection efficiency and explant viability.

\section{MATERIALS AND METHODS}

\section{Plant materials}

Rhizomes of $Z$. aethiopica L. 'SW 33-09' imported from California Callas (Golden State Bulb Growers, Moss Landing, CA) were purchased from Foreport Enterprises (Taipei, Taiwan). They were grown in plastic pots (18.5 $\mathrm{cm}$ diameter $\times 14.5 \mathrm{~cm}$ height) containing peat moss and perlite (3:1), and cultivated in a greenhouse at Chinese Culture University $\left(121^{\circ} 32^{\prime} 21.3^{\prime \prime} \mathrm{E}, 25^{\circ} 08^{\prime} 00.6^{\prime \prime}\right.$ $\mathrm{N})$ with daily irrigation. Newly formed small rhizomes on the main rhizomes (Fig. 1A) were used as the materials for in vitro cultures. After removing soil from the main rhizomes and thoroughly cleaning them with running tap water, small rhizomes with diameters of $<$ $1.5 \mathrm{~cm}$ were used for the sterilization experiments (Fig. 1B). The surface of each small rhizome was stripped off using Kimwipes pre-soaked in household POAS detergent (Nice Co., Chiayi, Taiwan) and rinsed with running tap water. Any damaged tissues of the small rhizomes were excised with a scalpel, and the processed rhizome materials were blotted on paper towels and then airdried for 10 minutes.

\section{Sterilization of rhizomes}

Rhizomes were thoroughly sprayed with $75 \%$ ethanol (v/v) and allowed to stand for 45 seconds. Hydrogen peroxide (36.5\% (w/v) $\mathrm{H}_{2} \mathrm{O}_{2}$, Sigma-Aldrich, St. Louis, MO), Clorox ${ }^{\circledR}$ bleach (5.25\% (w/v) NaOCl, Clorox, Oakland, CA), and Debalin ${ }^{\circledR}\left(50 \mathrm{~g} \cdot \mathrm{L}^{-1}\right.$ aqueous $\mathrm{ClO}_{2}$ solution, Gih-Hwa Co., Kaohsiung, Taiwan) were used as sanitizer stocks and diluted with distilled-deionized water (d.d. $\mathrm{H}_{2} \mathrm{O}$ ) to the indicated concentrations.

Experiment 1: Effect of pre-sterilization with $\mathrm{H}_{2} \mathrm{O}_{2}$ followed by $1 \% \mathrm{NaOCl}$ on explants

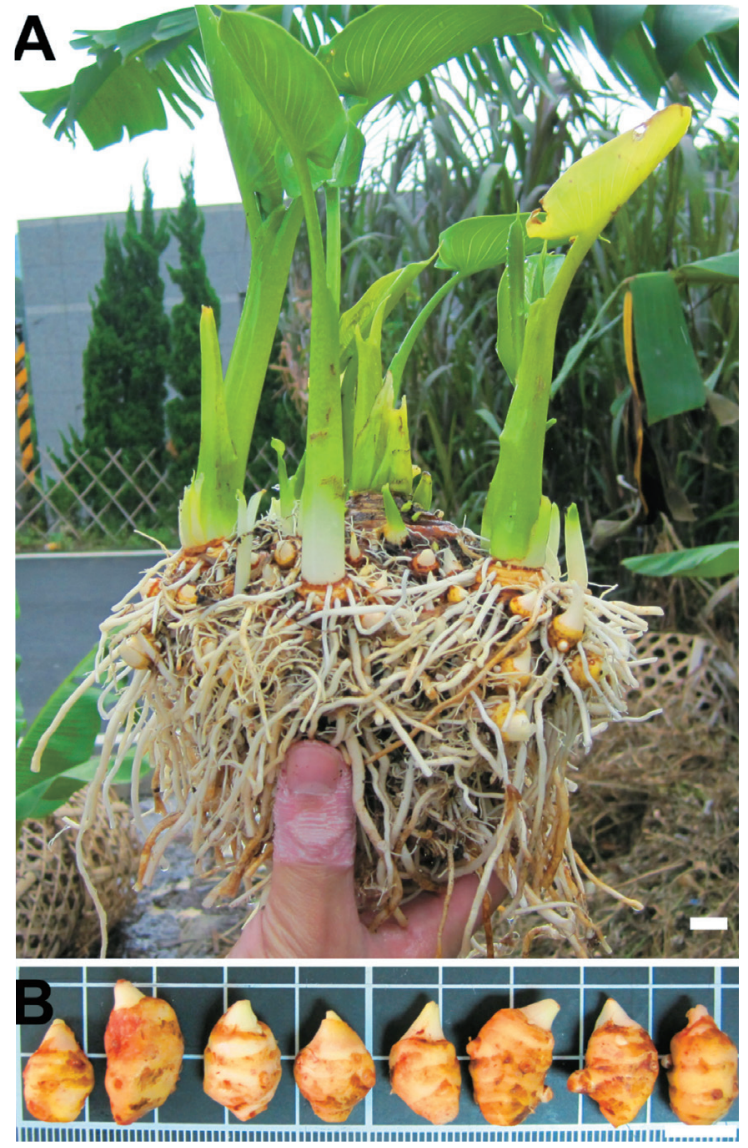

Fig. 1. Zantedeschia aethiopica was used for sterilization experiments. (A) Newly formed small rhizomes on the main rhizome. (B) Small rhizomes used for sterilization experiments. Scale bar $=5 \mathrm{~mm}$.

Rhizomes were pre-sterilized with $0 \%, 1 \%, 5 \%$, or $10 \% \mathrm{H}_{2} \mathrm{O}_{2}$ for 5 minutes by hand agitation, rinsed three times with d.d. $\mathrm{H}_{2} \mathrm{O}$, then sterilized with $1 \% \mathrm{NaOCl}$ containing $0.01 \%(\mathrm{v} / \mathrm{v})$ Tween-20 for 15 minutes, and rinsed three times again with d.d. $\mathrm{H}_{2} \mathrm{O}$.

Experiment 2: Application of $5 \% \mathrm{H}_{2} \mathrm{O}_{2}$ combined with $\mathrm{ClO}_{2}$ to sterilize explants

Rhizomes were pre-sterilized with $0 \%$ or $5 \% \mathrm{H}_{2} \mathrm{O}_{2}$ for 5 minutes by hand agitation, rinsed three times with d.d. $\mathrm{H}_{2} \mathrm{O}$, then sterilized with 60,120 , or $180 \mathrm{mg} \cdot \mathrm{L}^{-1} \mathrm{ClO}_{2}$ containing $0.01 \%$ Tween-20 for 15 minutes in the dark, and rinsed three times again with d.d. $\mathrm{H}_{2} \mathrm{O}$.

The shoot tip (1 2 $\mathrm{mm}$ in height) containing the basal rhizome segment was dissected from the sterilizedrhizome as the rhizome bud explant (Fig. 2A). Explants were cultured on MS basal medium containing fullstrength MS salts and vitamins (Murashige and Skoog, 1962 ), $100 \mathrm{mg} \cdot \mathrm{L}^{-1}$ myo-inoisitol, $30 \mathrm{~g} \cdot \mathrm{L}^{-1}$ sucrose, $1 \mathrm{~g} \cdot \mathrm{L}^{-1}$ active charcoal, and $8 \mathrm{~g} \cdot \mathrm{L}^{-1}$ plant agar. The $\mathrm{pH}$ of the medium was adjusted to 5.8, and medium was dispensed as $10-\mathrm{mL}$ aliquots into test tubes $(20 \times 150 \mathrm{~mm})$. The medium at $1 \mathrm{~kg} \cdot \mathrm{cm}^{-2}$ was autoclaved at $121^{\circ} \mathrm{C}$ for $15 \mathrm{~min}$ utes. Fourteen to 27 explants were used in each sterilization treatment with one explant per test tube, and all treatments consisted of three replicates. Explants were cultured in growth chamber (CH-202-A, Chin-Hsin, Taipei, Taiwan) at $22 \pm 1^{\circ} \mathrm{C}$ with light intensity of 


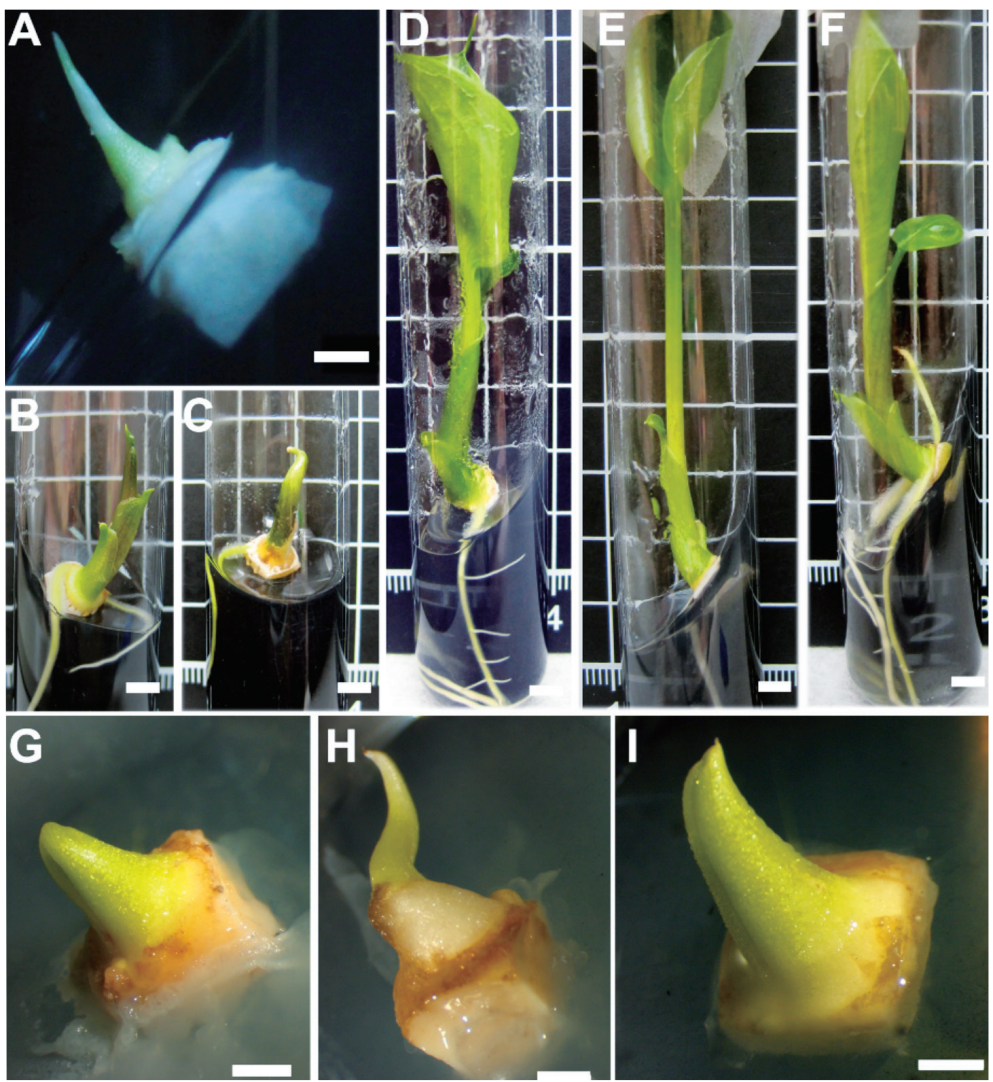

Fig. 2. Effect of different sterilization methods on micropropagation of Zantedeschia aethiopica in vitro. (A) A rhizome bud explant sterilized with $1 \% \mathrm{NaOCl}$, three days of culture (Scale bar $=2 \mathrm{~mm}$ ). (B) Shoot development in a rhizome bud explant sterilized with $5 \% \mathrm{H}_{2} \mathrm{O}_{2}$ and $1 \%$ $\mathrm{NaOCl}$, two days of culture. (C) Shoot growth retardation with $10 \% \mathrm{H}_{2} \mathrm{O}_{2}$ and $1 \% \mathrm{NaOCl}$, five weeks of culture. Plantlet growth of a rhizome bud explant sterilized with $5 \% \mathrm{H}_{2} \mathrm{O}_{2}$ and $1 \% \mathrm{NaOCl}$ (D), $120 \mathrm{mg} \cdot \mathrm{L}^{-1} \mathrm{ClO}_{2}(\mathrm{E})$, and $5 \% \mathrm{H}_{2} \mathrm{O}_{2}$ and $180 \mathrm{mg} \cdot \mathrm{L}^{-1} \mathrm{ClO}_{2}(\mathrm{~F})$, five weeks of culture. Scale bars in $\mathrm{B}-\mathrm{F}=5 \mathrm{~mm}$. Rhizome bud explants sterilized with $5 \% \mathrm{H}_{2} \mathrm{O}_{2}(\mathrm{G}, \mathrm{H})$, and $5 \% \mathrm{H}_{2} \mathrm{O}_{2}$ and $180 \mathrm{mg} \cdot \mathrm{L}^{-1} \mathrm{ClO}_{2}$ (I), five days of culture (Scale bars $=2 \mathrm{~mm}$ ).

$50 \mu \mathrm{mol} \cdot \mathrm{m}^{-2} \cdot \mathrm{s}^{-1}$ and 13 -hour photoperiod. Visible contamination of the explants and shoots was recorded after in vitro culture for five weeks. The percentage of contamination was calculated as the number of contaminated explants divided by the total number of explants. The rate of explants showing shoot development was calculated as the number of explants showing shoot development divided by total number of surviving explants. Shoot height was the average height of shoots developing from the surviving explants.

\section{Statistical analysis}

Data from experiments 1 and 2 were subjected to a one-way analysis of variance (ANOVA), with a significance level of $P<0.05$ using CoStat statistical software (Cohort Berkeley, Monterey, CA). Significant differences were determined using the Student-Newman-Keuls test. Synergistic effects of $\mathrm{H}_{2} \mathrm{O}_{2}$ and $\mathrm{ClO}_{2}$ on sterilizing rhizome bud explants were analyzed by a two-factor completely randomized ANOVA, which compared $\mathrm{H}_{2} \mathrm{O}_{2}$ and $\mathrm{ClO}_{2}$. For significant values, means were separated by the least significant difference (LSD) test at $P \leq 0.05,0.01$ or 0.001, using CoStat.

\section{RESULTS}

Effect of pre-sterilization with $\mathrm{H}_{2} \mathrm{O}_{2}$ on the sterilization efficiency of $\mathrm{NaOCl}$

Table 1 illustrates that sterilization of rhizome bud explants with $1 \% \mathrm{NaOCl}$ for 15 minutes resulted in a high contamination percentage of $73.3 \%$ and a low survival rate of $25.9 \%$. Pre-sterilization with both $1 \%$ and $0 \%$ (control) $\mathrm{H}_{2} \mathrm{O}_{2}$ showed no significant effect on eliminating the contaminants in vitro. However, application of $5 \%$ or $10 \% \mathrm{H}_{2} \mathrm{O}_{2}$ for 5 minutes followed by $1 \% \mathrm{NaOCl}$ significantly decreased in vitro contamination and increased survival rates to $60.0 \%$ and $42.9 \%$, respectively. To evaluate the impact of $\mathrm{H}_{2} \mathrm{O}_{2}$ on shoot growth, the shoot height and frequency of explants showing shoot development were determined, and results showed that there were no significant differences in shoot growth or development among pre-sterilization with $0 \%$ to $5 \%$ $\mathrm{H}_{2} \mathrm{O}_{2}$. The rates of explants showing shoot development ranged from $53.7 \%$ to $66.7 \%$, and the average shoot height was from 6.8 to $7.7 \mathrm{~cm}$ after culture of five weeks, indicating that most shoot tips still retained more than $50 \%$ viability after pre-sterilization with $\mathrm{H}_{2} \mathrm{O}_{2}$ (Fig. 2B, 
Table 1. Supplementary effects of $\mathrm{H}_{2} \mathrm{O}_{2}$ as a pre-disinfectant on rhizome bud explants of Zantedeschia aethiopica sterilized with $1 \% \mathrm{NaOCl}$

\begin{tabular}{|c|c|c|c|c|}
\hline $\begin{array}{c}\text { Concentration } \\
(\%)\end{array}$ & $\begin{array}{c}\text { Contamination } \\
(\%)\end{array}$ & $\begin{array}{c}\text { Survival rate } \\
(\%)\end{array}$ & $\begin{array}{c}\text { Explants showing shoot } \\
\text { development/explants } \\
\text { surviving (\%) }\end{array}$ & $\begin{array}{l}\text { Shoot height } \\
\text { (cm) }\end{array}$ \\
\hline 0 & $73.3 \pm 0.7^{\mathrm{a}}$ & $25.9 \pm 0.7^{c}$ & $65.1 \pm 4.2^{\mathrm{a}}$ & $7.3 \pm 0.1^{\mathrm{a}}$ \\
\hline 1 & $78.0 \pm 2.8^{\mathrm{a}}$ & $27.3 \pm 2.8^{c}$ & $66.7 \pm 9.6^{\mathrm{a}}$ & $7.7 \pm 0.5^{\mathrm{a}}$ \\
\hline 5 & $34.6 \pm 4.8^{\mathrm{c}}$ & $60.0 \pm 4.8^{\mathrm{a}}$ & $53.7 \pm 4.3^{\mathrm{ab}}$ & $6.8 \pm 0.1^{\mathrm{a}}$ \\
\hline 10 & $59.9 \pm 1.9^{b}$ & $42.9 \pm 1.9^{b}$ & $37.9 \pm 2.8^{\mathrm{b}}$ & $1.8 \pm 0.2^{\mathrm{b}}$ \\
\hline
\end{tabular}

Data were recorded five weeks after culture, calculated from three replicates each containing 15-27 samples, and expressed as the mean \pm SE. Different superscript letters indicate a significant difference at $P<0.05$ according to a one-way ANOVA and the Student-Newman-Keuls test.

2D). However, shoot tips derived from rhizomes presterilized with $10 \% \mathrm{H}_{2} \mathrm{O}_{2}$ severely lost viability, resulting in a low rate of explants showing shoot development (37.9\%) and retardation of shoot growth (Fig. 2C). It should be noted that rhizomes pre-sterilized with $5 \%$ $\mathrm{H}_{2} \mathrm{O}_{2}$ followed by $1 \% \mathrm{NaOCl}$ effectively decreased in vitro contamination to less than $35 \%$ with minimal effects on shoot growth or development.

\section{The synergistic effect of $\mathrm{H}_{2} \mathrm{O}_{2}$ and $\mathrm{ClO}_{2}$ on steriliza- tion}

In experiment 2 , each treatment was assumed to be dependent on the other. ANOVA results of main effects of $\mathrm{H}_{2} \mathrm{O}_{2}, \mathrm{ClO}_{2}$, and their interaction effect on rhizome bud explants are summarized in Table 2. Contamination, survival rates, and shoot height (with $\mathrm{H}_{2} \mathrm{O}_{2}$ treatment) significantly differed at the levels of $0.1 \%$ or $1 \%$ for the main effects, except for shoot height (with $\mathrm{ClO}_{2}$ treatment) and shoot development which showed negligible differences. Moreover, only shoot height significantly differed in interaction effects.

To investigate the sterilization efficiency of $\mathrm{ClO}_{2}$ on rhizome bud explants and its synergistic effect with 5\% $\mathrm{H}_{2} \mathrm{O}_{2}$, six sterilization conditions, including $0 \%$ or $5 \% \mathrm{H}_{2} \mathrm{O}_{2}$ for 5 minutes in combination with 60,120 , or $180 \mathrm{mg} \cdot \mathrm{L}^{-1}$ $\mathrm{ClO}_{2}$ for 15 minutes were implemented. Table 3 reveals that in vitro contamination of rhizome bud explants sterilized with $60-180 \mathrm{mg} \cdot \mathrm{L}^{-1} \mathrm{ClO}_{2}$ for 15 minutes ranged from $68.3 \%$ to $83.0 \%$, and survival rates were only $16.7 \%$ to $31.7 \%$. Compared to $60 \mathrm{mg} \cdot \mathrm{L}^{-1} \mathrm{ClO}_{2}$, both 120 and $180 \mathrm{mg} \cdot \mathrm{L}^{-1} \mathrm{ClO}_{2}$ displayed better disinfection efficacies and survival rates, and shoot tips grew equally well (Fig. 2E). Notably, the rates of shoot-developing explants treated with 120 or $180 \mathrm{mg} \cdot \mathrm{L}^{-1} \mathrm{ClO}_{2}(75.9 \%-88.6 \%)$ were

Table 2. ANOVA of $\mathrm{H}_{2} \mathrm{O}_{2}, \mathrm{ClO}_{2}$, and their interaction for contamination, survival rate, shoot development, and shoot height of rhizome bud explants of Zantedeschia aethiopica

\begin{tabular}{cccccc}
\hline \multirow{2}{*}{$\begin{array}{c}\text { Source of } \\
\text { variance }\end{array}$} & $\begin{array}{c}\text { Degrees of } \\
\text { freedom }\end{array}$ & Contamination & Survival rate & Shoot development & Shoot height \\
\cline { 3 - 6 } $\mathrm{H}_{2} \mathrm{O}_{2}$ & 1 & $* * *$ & $* * *$ & $\mathrm{~ns}$ & $* *$ \\
$\mathrm{ClO}_{2}$ & 2 & $* *$ & $* *$ & $\mathrm{~ns}$ & $\mathrm{~ns}$ \\
$\mathrm{H}_{2} \mathrm{O}_{2} \times \mathrm{ClO}_{2}$ & 2 & $\mathrm{~ns}$ & $\mathrm{~ns}$ & $\mathrm{~ns}$ \\
\hline
\end{tabular}

*** $P<0.001, * * P<0.01, * P<0.05$, ns: non-significant difference.

Table 3. The synergistic effect of $\mathrm{H}_{2} \mathrm{O}_{2}$ and $\mathrm{ClO}_{2}$ on sterilization of rhizome bud explants of Zantedeschia aethiopica

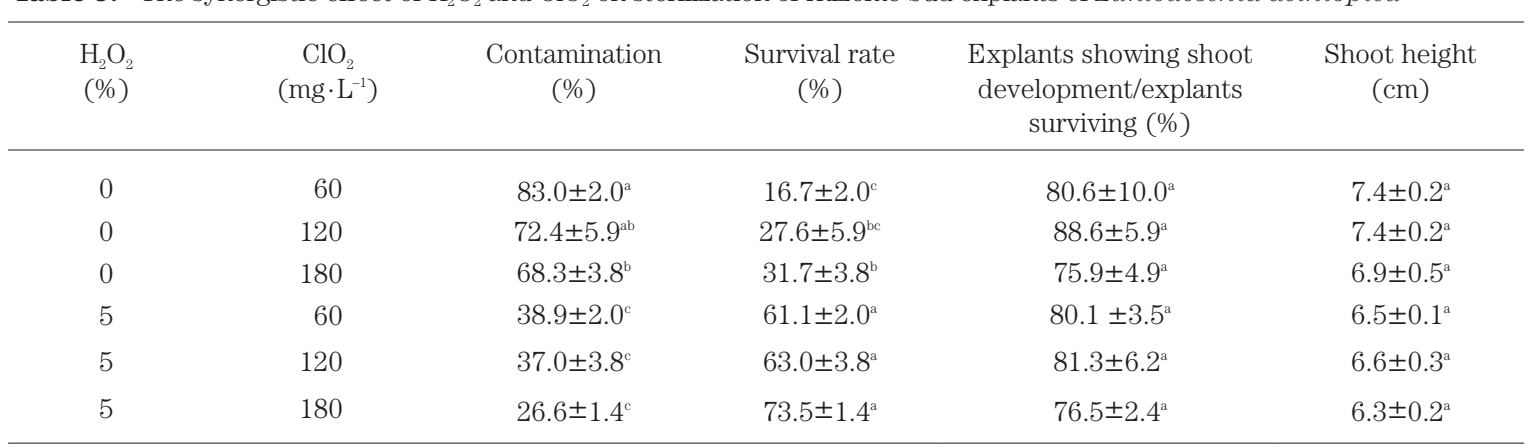

Data were recorded five weeks after culture, calculated from three replicates each containing 14-24 samples, and expressed as the mean \pm SE. Different superscript letters indicate a significant difference at $P<0.05$ according to a oneway ANOVA and the Student-Newman-Keuls test. 
higher than that treated with $1 \% \mathrm{NaOCl}(65.1 \%)$ (Table 1). Therefore, both 120 and $180 \mathrm{mg} \cdot \mathrm{L}^{-1} \mathrm{ClO}_{2}$ could be substituted for $1 \% \mathrm{NaOCl}$ to sterilize rhizome explants with a higher frequency of shoot development. When pre-sterilized with $5 \% \mathrm{H}_{2} \mathrm{O}_{2}$ followed by 60,120 , and $180 \mathrm{mg} \cdot \mathrm{L}^{-1} \mathrm{ClO}_{2}$, in vitro contamination of rhizome bud explants was significantly decreased to low rates of $26.6 \%$ to $38.9 \%$, and survival rates increased to high rates of $61.1 \%$ to $73.5 \%$ without any influence on shoot growth or development (Table 3), indicating that pre-sterilization with $5 \% \mathrm{H}_{2} \mathrm{O}_{2}$ can supplement the disinfection efficacy of $\mathrm{ClO}_{2}$. Moreover, two-step sterilization with $\mathrm{H}_{2} \mathrm{O}_{2}$ and $\mathrm{ClO}_{2}$ improved the rate of shoot-developing explants to $76.5 \%-81.3 \%$, compared to those with $\mathrm{H}_{2} \mathrm{O}_{2}$ and $\mathrm{NaOCl}$ (53.7\%). After pre-sterilization with $\mathrm{H}_{202}, \mathrm{NaOCl}$ caused more damage to rhizome bud explants than $\mathrm{ClO}_{2}$, and resulted in a lower rate of explants showing shoot development (Table 1). Furthermore, $82.6 \%$ of explant tissues $(n=23)$ were contaminated when sterilized with $5 \% \mathrm{H}_{2} \mathrm{O}_{2}$ only (Fig. 2G, H). Apparently, 5\% $\mathrm{H}_{2} \mathrm{O}_{2}$ and $60-180 \mathrm{mg} \cdot \mathrm{L}^{-1} \mathrm{ClO}_{2}$ have synergistic effects on eliminating contaminants for in vitro culture and maintaining the viability of rhizome bud explants of calla lily (Fig. 2F, 2I).

\section{DISCUSSION}

Both $\mathrm{H}_{2} \mathrm{O}_{2}$ and $\mathrm{ClO}_{2}$ act effectively against microorganisms and exhibit low phytotoxicity due to size-selectivity of $\mathrm{ClO}_{2}$ and reduction of extracellular $\mathrm{H}_{2} \mathrm{O}_{2}$ by catalases in Lilium (Curvetto et al., 2006; Noszticzius et al., 2013). They are also used as alternative sterilizers for sterilizing culture media (Cardoso and da Silva, 2012) and explants of crop (Bhawana et al., 2015; Duan et al., 2016). The concentration and incubation time of $\mathrm{H}_{2} \mathrm{O}_{2}$ for in vitro sterilization vary and are dependent on plant species and explant type. Additionally, working concentrations of the disinfectant and sterilization time are also important for achieving the best efficiency of sterilization. A low concentration $(<0.2 \%)$ of $\mathrm{H}_{2} \mathrm{O}_{2}$ was used to substitute for autoclaving of culture medium of Lilium (Curvetto et al., 2006), and sterilizing orchid seeds (Snow, 1985). Miché and Balandreau (2001) sterilized rice seeds with $10 \% \mathrm{H}_{2} \mathrm{O}_{2}$ for 10 minutes followed by $1 \%$ calcium hypochlorite for 1 hour, and found that chloramines derived from the reaction of hypochlorite with ammonia caused mutations of seedlings. In this study, we combined the advantages of $\mathrm{H}_{2} \mathrm{O}_{2}$ and $\mathrm{ClO}_{2}$ in sterilizing rhizome bud explants of $Z$. aethiopica and simultaneously preventing damage to plant cells. Pre-sterilization with $5 \% \mathrm{H}_{2} \mathrm{O}_{2}$ for 5 minutes effectively enhanced the disinfection efficiency of $1 \% \mathrm{NaOCl}$ or $60-180 \mathrm{mg} \cdot \mathrm{L}^{-1}$ $\mathrm{ClO}_{2}$ for micropropagation of $Z$. aethiopica in vitro. Although calla lily explants sterilized with $1 \% \mathrm{NaOCl}$ for 15 minutes exhibited a high incidence of contamination (73.3\%), pre-sterilization with $5 \% \mathrm{H}_{2} \mathrm{O}_{2}$ for 5 minutes significantly compensated for the low sterilization efficiency of $1 \% \mathrm{NaOCl}$.

Due to chlorination-caused health risks and environment hazards, $\mathrm{ClO}_{2}$ has been widely used as an alter- native disinfectant for drinking and irrigation water instead of hypochlorite (Noszticzius et al., 2013). The germicidal efficiency of $\mathrm{ClO}_{2}\left(\geq 1.4 \mathrm{mg} \cdot \mathrm{L}^{-1}\right)$ is stable in a wide $\mathrm{pH}$ range of 3.0-9.0 and more effective than liquid chlorine in killing Escherichia coli, Staphylococcus aureus, Bacillus subtilis, Sarcina, and disinfection of domestic wastewater (Huang et al., 1997). $\mathrm{ClO}_{2}$ also killed several phytopathogens, including Erwinia carotovora, which causes bacterial soft rot and seriously impacts the production of calla lily (Snijder et al., 2004; Yoa et al., 2010). Moreover, fumigation of longan fruit with $10 \mathrm{mg} \cdot \mathrm{L}^{-1} \mathrm{ClO}_{2}$ for 10 minutes reduced the production of ROS and prevented membrane damage during storage against oxidative browning (Chomkitichai et al., 2014). Cardoso and da Silva (2012) reported that shoot tips of gerbera grew and developed better in culture medium sterilized with $25-100 \mathrm{mg} \cdot \mathrm{L}^{-1} \mathrm{ClO}_{2}$ than with autoclaving. Gaseous and aqueous $\mathrm{ClO}_{2}$ have also been extensively used in the surface decontamination of plant explants; however, their effective concentrations differ. Cauliflower curds were successfully sterilized with $\mathrm{ClO}_{2}$ gas at high concentrations of 600 and $1500 \mathrm{mg} \cdot \mathrm{L}^{-1}$ for 60-360 minutes and still remained viable (Bhawana et al., 2015). However, there are safety concerns with gaseous $\mathrm{ClO}_{2}$ due to an explosive risk at high concentrations (Duan et al., 2016). Sterilization with aqueous $\mathrm{ClO}_{2}$ at low concentrations of $84-168 \mathrm{mg} \cdot \mathrm{L}^{-1}$ for $40-80$ minutes effectively disinfected explants of low polyphenol-containing plant species, such as rice, yacon, Pinellia trenata, and Isodon amethystoides (Duan et al., 2016). Nevertheless, in our study, application of $60-180 \mathrm{mg} \cdot \mathrm{L}^{-1}$ $\mathrm{ClO}_{2}$ for sterilizing rhizome bud explants of calla lily was not efficient enough to be practical, while explants maintained higher viability than with hypochlorite. This may have been due to a short sterilization time of only 15 minutes. Compared to the combination of $5 \% \mathrm{H}_{2} \mathrm{O}_{2}$ and $1 \% \mathrm{NaOCl}$, pre-sterilization with $5 \% \mathrm{H}_{2} \mathrm{O}_{2}$ for 5 minutes not only supplemented the low efficiency of sterilization with $60-180 \mathrm{mg} \cdot \mathrm{L}^{-1} \mathrm{ClO}_{2}$, but also retained a higher viability of explants for development of shoot meristems. Supposedly, $\mathrm{ClO}_{2}$ contributes to the reduction reaction of $\mathrm{H}_{2} \mathrm{O}_{2}$ or $\mathrm{O}_{2}{ }^{--}$to non-toxic oxygen and triggers the antioxidant defense system to avoid oxidative damage to explants during sterilization.

\section{Conclusion}

Our results provide an optimized strategy for sterilizing field-grown plant materials and improving the vigor and viability of explants. Two-step sterilization with 5\% (w/v) $\mathrm{H}_{2} \mathrm{O}_{2}$ and $60-180 \mathrm{mg} \cdot \mathrm{L}^{-1} \mathrm{ClO}_{2}$ offers advantages of a high sterilization efficiency and low phytotoxicity, which can overcome the disadvantages of conventional sterilization methods with hypochlorite, fungicides or antibiotics.

\section{ACKNOWLEDGMENT}

This work was supported by the Ministry of Science and Technology, Taiwan, ROC [NSC101-2313-B-034 -001], and the Council of Agriculture, Taiwan, ROC 
[103AS-9.1.1-FD-Z2]

\section{REFERENCES}

Bhawana, J. M. Stubblefield, A. L. Newsome and A. B. Cahoon 2015 Surface decontamination of plant tissue explants with chlorine dioxide gas. In Vitro Cell. Dev. Biol. Plant, 51: 214219

Cardoso, J. C. and J. A. T. da Silva 2012 Micropropagation of gerbera using chlorine dioxide $\left(\mathrm{ClO}_{2}\right)$ to sterilize the culture medium. In Vitro Cell. Dev. Biol. Plant, 48: 362-368

Chang, H. S., D. Chakrabarty, E. J. Hahn and K. Y. Paek 2003 Micropropagation of calla lily (Zantedeschia albomaculata) via in vitro shoot tip proliferation. In Vitro Cell. Dev. Biol. Plant, 39: 129-134

Chen, L. R., J. T. Chen and W. C. Chang 2002 Efficient production of protocorm-like bodies and plant regeneration from flower stalk explants of the sympodial orchid Epidendrum radicans. In Vitro Cell. Dev. Biol. Plant, 28: 441-445

Chomkitichai, W., A. Chumyam, P. Rachtanapun, J. Uthaibutra and K. Saengnil 2014 Reduction of reactive oxygen species production and membrane damage during storage of 'Daw' longan fruit by chlorine dioxide. Scientia Hort., 170: 143-149

Curvetto, N., P. Marinangeli and G. Mockel 2006 Hydrogen peroxide in micropropagation of Lilium. A comparison with a traditional methodology. Biocell, 30: 497-500

Duan, Y., F. Zhao, H. Li, Y. Zhou, X. Zhu, F. Li, W. Chen and J. Xue 2016 Evaluation of aqueous chlorine dioxide for disinfecting plant explants. In Vitro Cell. Dev. Biol. Plant, 52: 38-44

Ebrahim, M. K. H. 2004 Comparison, determination and optimizing the conditions required for rhizome and shoot formation, and flowering of in vitro cultured calla explants. Scientia Hort., 101: 305-313

Errampalli, D., R. D. Peters, K. Maclsaac, D. Darrach and P. Boswall 2006 Effect of a combination of chlorine dioxide and thiophanate-methyl pre-planting seed tuber treatment on the control of black scurf of potatos. Crop Prot., 25: 1231-1237

Fukuzaki, S. 2006 Mechanisms of actions of sodium hypochlorite in cleaning and disinfection processes. Biocontrol Sci., 11: $147-157$

Gagnon, G. A., J. L. Rand, K. C. O'Leary, A. C. Rygel, C. Chauret and R. C. Andrews 2005 Disinfectant efficacy of chlorite and chlorine dioxide in drinking water biofilms. Water Res., 39: 1809-1817

Ghimire, B. K., C. Y. Yu, H. J. Kim and I. M. Chung 2012 Karyotype and nucleic acid content in Zantedeschia aethiopica Spr. and Zantedeschia elliottiana Engl. Afr. J. Biotechnol., 11: 11604-11609

Herczegh, A., A. Ghidan, D. Friedreich, M. Gyurkovics, Z. Bendö and Z. Lohinai 2013 Effectiveness of a high purity chlorine dioxide solution in eliminating intracanal Enterococcus faecalis biofilm. Acta Microbiol. Immunol. Hung., 60: 63-75
Huang, J., L. Wang, N. Ren, F. Ma and Juli 1997 Disinfection effect of chlorine dioxide on bacteria in water. Water Res., 31: 607613

Kritzinger, E. M., R. J. V. Vuuren, B. Woodward, I. H. Rong, M. H. Spreeth and M. M. Slabbert 1998 Elimimation of external and internal contaminants in rhizomes of Zantedeschia aethiopica with commercial fungicides and antibiotics. Plant Cell Tiss. Org. Cult., 52: 61-65

Linley, E., S. P. Denyer, G. McDonnell, C. Simons and J. Y. Maillard 2012 Use of hydrogen peroxide as a biocide: new consideration of its mechanisms of biocidal action. J. Antimicrob. Chemother., 67: 1589-1596

Maina, S. M., Q. Emongor, K. K. Sharma, S. T. Gichuki, M. Gathaara, S. M. de Villiers 2010 Surface sterilant effect on the regeneration efficiency from cotyledon explants of groundnut (Arachis hypogea L.) varieties adapted to eastern and Southern Africa. Afr. J. Biotechnol., 9: 2866-2871

Miché, L. and J. Balandreau 2001 Effects of rice seed surface sterilization with hypochlorite on inoculated Burkholderia vietnamiensis. Appl. Environ. Microbiol., 67: 3046-3052

Mihaljević, I., K. Dugalić, V. Tomaš, M. Viljevac, A. Pranjić, Z. Čmelik, B. Puškar and Z. Jurkovć 2013 In vitro sterilization procedures for micropropagation of 'Oblačinska' sour cherry. J. Agric. Sci., 58: 117-126

Mngómba, S. A., G. Sileshi, E. S. du Toit and F. K. Akinnifesi 2012 Efficacy and utilization of fungicides and other antibiotics for aseptic plant cultures. In "Fungicides for Plant and animal diseases", ed. by D. Dhanasekaran, InTech, Inc. Rijeka, Croatia, pp. $245-254$

Murashige, T. and F. Skoog 1962 A revised medium for rapid growth and bio assays with tobacco tissue cultures. Physiol. Plant., 15: 473-497

Noszticzius, Z., M. Wittmann, K. Kály-Kullai, Z. Beregvári, I. Kiss, L. Rosivall and J. Szegedi 2013 Chlorine dioxide is a sizeselective antimicrobial agent. PLOS ONE, 8: e79157

Rutala, W. A. and D. J. Weber 1997 Uses of inorganic hypochlorite (Bleach) in health-care facilities. Clin. Microbiol. Rev., 10 597-610

Snijder, R. C., H. R. Cho, M. M. W. B. Hendriks, P. Lindhout and J. M. van Tuyl 2004 Genetic variation in Zantedeschia spp. (Araceae) for resistance to soft rot caused by Erwinia carotovora subsp. carotovora. Euphytica, 135: 119-128

Snow, R. 1985 Improvements in methods for the germination of orchid seeds. Am. Orch. Soc. Bull., 54: 178-181

Srebernich, S. M. 2007 Using chlorine dioxide and peracetic acid as substitutes for sodium hypocloride in the sanitization of minimally processed green seasoning. Ciênc. Tecnol. Aliment., 27: 744-750

Yao, K. S., Y. H. Hsieh, Y. J. Chang, C. Y. Chang, T. C. Cheng and H. L. Liao 2010 Inactivation effect of chlorine dioxide on phytopathogenic bacteria in irrigation water. J. Environ. Eng. Manage., 20: 157-160 